\title{
SISTEM APLIKASI PENGOLAHAN NILAI RAPORT SDN TANJUNGANOM 2 KECAMATAN TANJUNGANOM NGANJUK
}

\author{
Hesty Puspita Sari ${ }^{1)}$, Retno Muhartini' ${ }^{2)}$ \\ ${ }^{(1)}$ Universitas Islam Balitar Blitar, ${ }^{(2)}$ SDN Tanjunganom 2 Nganjuk
}

\begin{abstract}
Abstrak: Dalam pengolahan nilai raport di SDN Tanjunganom 2 Nganjuk saat ini masih bersifat manual, sehingga banyak waktu dan tenaga diperlukan untuk menyelesaikan tugas tersebut. Tujuan dari penelitian ini adalah mengembangkan aplikasi pengolahan nilai bersifat komputerisasi. Upaya dalam pengolahan data dan informasi akan berhasil dengan perubahan yang lebih baik pada sistem yang ada (Microsot Excel). Aplikasi pengolahan nilai raport SDN Tanjunganom 2 Kecamatan Tanjunganom Kabupaten Nganjuk adalah aplikasi yang menangani pengolahan nilai raport K13 yang memiliki banya komponen mata pelajaran yang didapatkan para siswa SDN Tanjunganom 2. Pengolahan nilai ini meliputi penilaian spiritual, sosial, pengetahuan per Kompetenesi dasar dan Ketrampilan perkompetensi Dasar, termasuk juga ekstrakulikuler siswa, kepribadian dan ketidakhadiran siswa. Dalam aplikasi ini juga terdapat pendataan yang diperlukan dalam pengolahan nilai yaitu pendataan siswa, guru, mata pelajaran, kelas dan ekstakulikuler. Aplikasi ini dikembangkan dengan menggunakan Microsoft excel.
\end{abstract}

Kata kunci: sistem aplikasi, nilai raport

\section{a. Latar Belakang}

\section{PENDAHULUAN}

Proses pembelajaran pada Kurikulum 2013 merupakan upaya untuk mencapai Kompetensi Dasar yang dirumuskan dalam kurikulum. Sementara itu, kegiatan penilaian dilakukan untuk mengukur dan menilai tingkat pencapaian Kompetensi Dasar. Penilaian juga digunakan untuk mengetahui kekuatan dan kelemahan dalam proses pembelajaran, sehingga dapat dijadikan dasar untuk pengambilan keputusan, dan perbaikan proses pembelajaran yang telah dilakukan. Oleh sebab itu kurikulum yang baik dan proses pembelajaran yang benar perlu di dukung oleh sistem penilaian yang baik, terencana dan berkesinambungan.

SDN tanjunganom 2 termasuk salah satu Sekolah dasar di Kabupaten Nganjuk yang sudah mengaplikasikan pembelajaran kurikulum 2013. Sehingga menuntut 
guru dan staf untuk mengembangkan teknik teknik penilaian yang sempurna. Penggunaan komputer sangat bermanfaat dan membantu pekerjaan menjadi lebih baik, cepat, dan efesien. Penggunaan komputer khususnya akan sangat bermanfaat dalam pengolahan nilai raport di SDN Tanjunganom 2. Namun dalam hal pengolahan nilai raport, masih menggunakan hitungan pena dan kalkulator. Hal ini akan menyita waktu dan tenaga guru dalam pengerjaannya.

Upaya dalam pengolahan data dan informasi akan lebih mudah dan berhasil dengan perubahan yang lebih baik pada sistem yang ada (Microsot Excel). Sehingga apabila terjadi kesalahan dan keterlambatan saat perhitungan pengolahan nilai yang banyak menyita waktu dan membutuhkan banyak tenaga dapat diperkecil.

Untuk itu, penulis membuat sistem aplikasi pengolahan nilai raport agar kemudahan, kecepatan dan ketepatan dalam pengolahan data khususnya nilai raport dapat terlaksana sehingga diharapkan dapat membawa kemajuan untuk SDN Tanjunanom 2 dan sekolah sekolah yang lain.

\section{b. Batasan Masalah}

Adapun batasan masalah penelitian sebagai berikut:

1. Program aplikasi komputersasi pengolahan nilai yang terdiri dari data siswa, data guru, nilai spiritual, nilai sosial, nilai ketrampilan per kompetensi dasar, nlai pengetahuanper kompetensi dasar, beserta nilai ektrakurikuler.

2. Mail merge untuk menghasilkan raport kurikulum 2012

\section{a. Sistem aplikasi}

\section{LANDASAN TEORI}

Sistem adalah serangkaian subsistem yang saling terkait dan tergantung satu sama lain, bekerja bersama-sama untuk mencapai tujuan dan sasaran yang sudah ditetapkan sebelumnya. Semua sistem memiliki input, proses, output, dan umpan balik. Contohnya adalah sistem informasi komputer; contoh lainnya adalah suatu organisasi (Kendall, 2003:25).

Dari definisi tersebut dapat diartikan bahwa sistem aplikasi adalah subkelas dari perangkat lunak (software) yang memanfaatkan komputer langsung untuk melakukan suatu tugas yang diingikan pengguna. Contoh utama aplikasi adalah aplikasi office yang berupa beberapa aplikasi yang dikemas menjadi satu paket seperti:

1. Aplikasi pengolah kata, contohnya microsoft word;

2. Aplikasi pengolah angka, contohnya mocrosoft excel;

3. Aplikasi pengolah basis data, contohnya microsoft access; dan 
4. Aplikasi pengolah presentasi, contohnya microsoft power point

b. Microsoft excel

Microsoft excel merupakan sebuah program aplikasi lembar kerja spreadsheet yang dibuat dan didistribusikan oleh microsoft corporation yang dapat dijalankan pada microsoft windows.

Apilkasi ini memiliki fitur kalkulasi dan pembuatan grafik sehingga sangat tepat dan mendukung untuk digunakan sebagai pengolahan nilai raport

\section{c. Nilai raport}

Raport berasal dari kata dasar report yang berarti laporan. Raport merupakan laporan hasil dari suatu kegiatan yang disusun secara tepat dan benar. Materi yang dilaporkan dalam hal ini adalah hasil Penilaian Akhir Semester, penilaian harian, tugas harian, ujian tengah semester, ujian akhir semester, kepribadian, ekstrakulikuler beserta data yang diperlukan yang berkaitan dengan raport

\section{METODE PENELITIAN}

Metode penelitian merupakan suat prosedur yang digunakan untuk mengumpulkan data, mengolah data, dan menganalisa data dengan teknik tertentu. Beberapa metode digunakan penulis dalam penelitian ini sebagai berikut:

\section{a. Lokasi Penelitian}

Dalam penelitian ini, penulis melakukan penelitian dengan mengambil objek penelitian pada SDN Tanjunanom 2 Kecamatan Tanjunanom Kabupaten Nganjuk.

\section{b. Data}

Data merupakan deskripsi dari suatu yang akan dikelola. Data dapat berupa catatan dalam dokumen dan file dalam data base. Dalam penelitian ini penulis menggunakan dua data sebagai berikut:

\section{Data Primer}

Data Primer adalah data yang langsung diperoleh dari sumber yang bersangkutan dengan cara wawancara dengan pihak sekolah berupa data mentah yang belum diolah. Data diperoleh dari Kepala Sekolah, Guru, dan operator Sekolah yang menangani sistem pengolahan nilai raport.

\section{Data Sekunder}

Data Sekunder adalah data yang diperoleh tak langsung atau melalui perantara dari suatu sumber atau objek yang sedang dilakukan penelitian tetapi mempunyai hubungan atau berkaitan

\section{c. Metode Pengumpulan Data}


Penulis menggunakan beberapa metode untuk mengumpulkan data sebagai berikut:

\section{Observasi}

Metode observasi merupakan suatu metode pengumpulan data dengan mengadakan pengamatan secara langsung, cermat dan sistematis atas gejala-gejala fenomena yang sedang di teliti dalam pengolahan nilai raport SDN Tanjunganom 2.

\section{Studi Pustaka}

Metode Studi Pustaka ialah salah satu pencarian dan pengumpulan data dengan cara menelaah mempelajari dan menyelesaikan di buku-buku mengenai penyelesaian masalah pengolahan nilai raport menggunakan aplikasi Microsoft excel.

\section{d. Langkah Penelitian}

\section{Tahap Analisa Data}

Dalam tahap ini penulis akan merancang sebuah sistem aplikasi penilaian Raport yang akan digunakan oleh SDN Tanjunganom 2 dan dapat dimanfaatkan oleh sekolah sekolah yang telah menerapkan kurikulum 2013.

Rancangan sistem aplikasi ini terdiri dari:

a) Data guru;

b) Data siswa;

c) Data walisiswa;

d) Data Kompetensi Dasar; dan

e) Data ekstra kurikuler siswa.

2. Tahap Desain

Dalam tahapan desain ini, penulis membuat sistem desain yang terdiri atas alat banu pengembangan sisetm sebagai berikut:

\section{a) Context Diagram (CD)}

Context Diagram adalah diagram aliran data yang paling dasar dari suatu organisasi yang menunjukkan bagaimana proses- proses mentransformasikan data yang datang ke informasi yang keluar. 


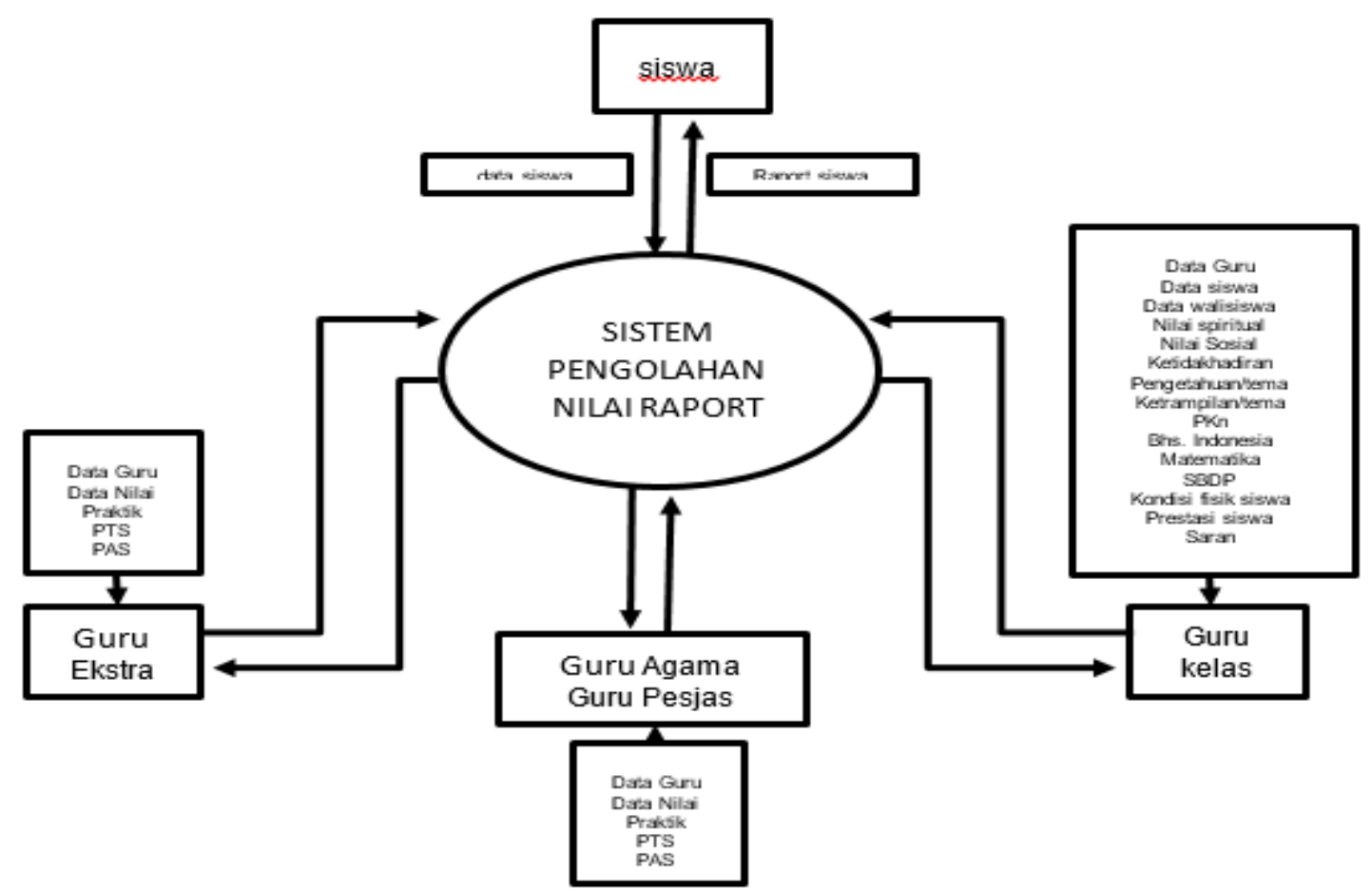

Gambar 1 Diagram Konteks

\section{b) Data Flow Diagram (DFD)}

DFD (Data Flow Diagram) adalah gambaran alir data atau informasi tanpa mengaitkan bentuk fisik media penyimpanan data atau hardware (Kendall, 2003). DFD merupakan alat bantu yang berfungsi untuk menggambarkan secara rinci mengenai sistem sebagai jaringan kerja antar fungsi yang berhubungan satu sama lain dengan menunjukkan dari dan kemana data mengalir serta penyimpangannya.

\section{c) ERD (Entity Relationship Diagram)}

ERD (Entity Relationship Diagram) adalah diagram yang berguna untuk memodelkan sistem yang nantinya akan dikembangkan dalam basis datanya. ERD (Entity Relationship Diagram) terusan atas 3 (tiga) komponen, yaitu entitas, atribut dan keselarasan antar entitas. Secara garis besar, entitas merupakan objek dasar yang terlihat dalam sistem. Atribut berperan sebagai penjelas entitas, dan kerapian menunjukan hubungan yang terjadi diantara 2 (dua) entitas (Sutanta, 2004).

\section{Tahap Penerapan sistem}

Perancangan dan implementasi program yang sudah siap akan diterapkan pada tahap ini. Dengan kriteria program dapat digunakan dengan mudah dan dipahami oleh pengguna. Perancangan program harus mengacu pada alir data yan telah dibuat 
terlebih dahulu. Untuk itu perlu adanya dukungan perangkat komputer yang memadai yang akan digunakan untuk membangun aplikasi ini secara optimal. Printer akan diperlukan sebagai pertimbangan kebutuhan dalam pencetakan nilai raport.

\section{a. Hasil perancangan sistem}

\section{HASIL DAN BAHASAN}

Perancangan sistem merupakan tahapan yang sangat penting untuk memperbaiki efisiensi kerja suatu sistem yang telah ada. Dalam tahap ini merupakan gambaran tahap untuk membangun suatu sistem dan mengkonfigurasikan beberapa komponen lunak dan keras sehingga menghasilkan sistem yang lebih baik.

Penerapan sistem aplikasi ini sangat mudah dipahami oleh pengguna meskipun pengguna pemula. Sistem aplikasi menggunakan aplikasi microsoft excel yang sudah dimasukkan rumus rumus penilaiannya sehingga guru maupun operator sekolah cukup menginput data pada kolom yang sudah disediakan.

1. Data siswa

Pengisian data siswa harus dilakukan dengan lengkap untuk tampilan halaman identitas siswa

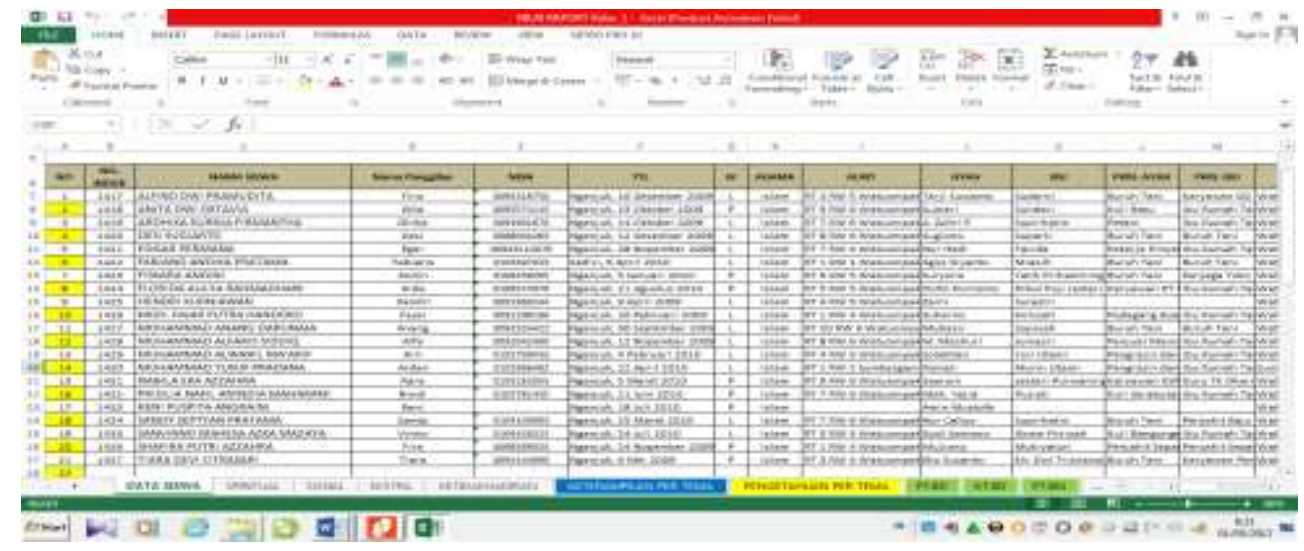

Gambar 2 Data siswa

\section{Nilai Spiritual}

Nilai spiritual adalah nilai kepribadian keagamaan siswa yang terdiri bagaimana sikap dan kebiasaan siswa setiap hari serta penerapan rasa syukur. 


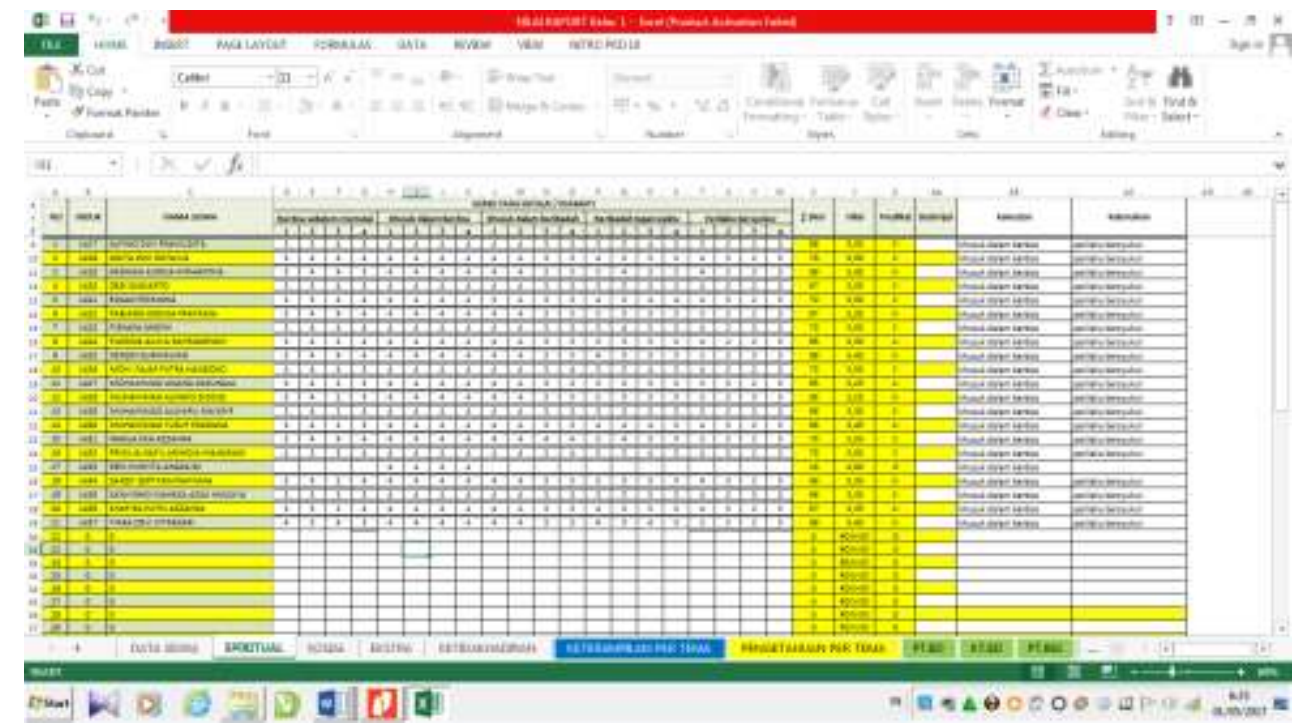

Gambar 3. Nilai spiritual siswa

\section{Nilai Sosial}

Nilai sosial adalah nilai kepribadian siswa yang meliputi tanggungjawab, jujur, peduli, sopan santun, percaya diri, kerjasama dan disiplin.

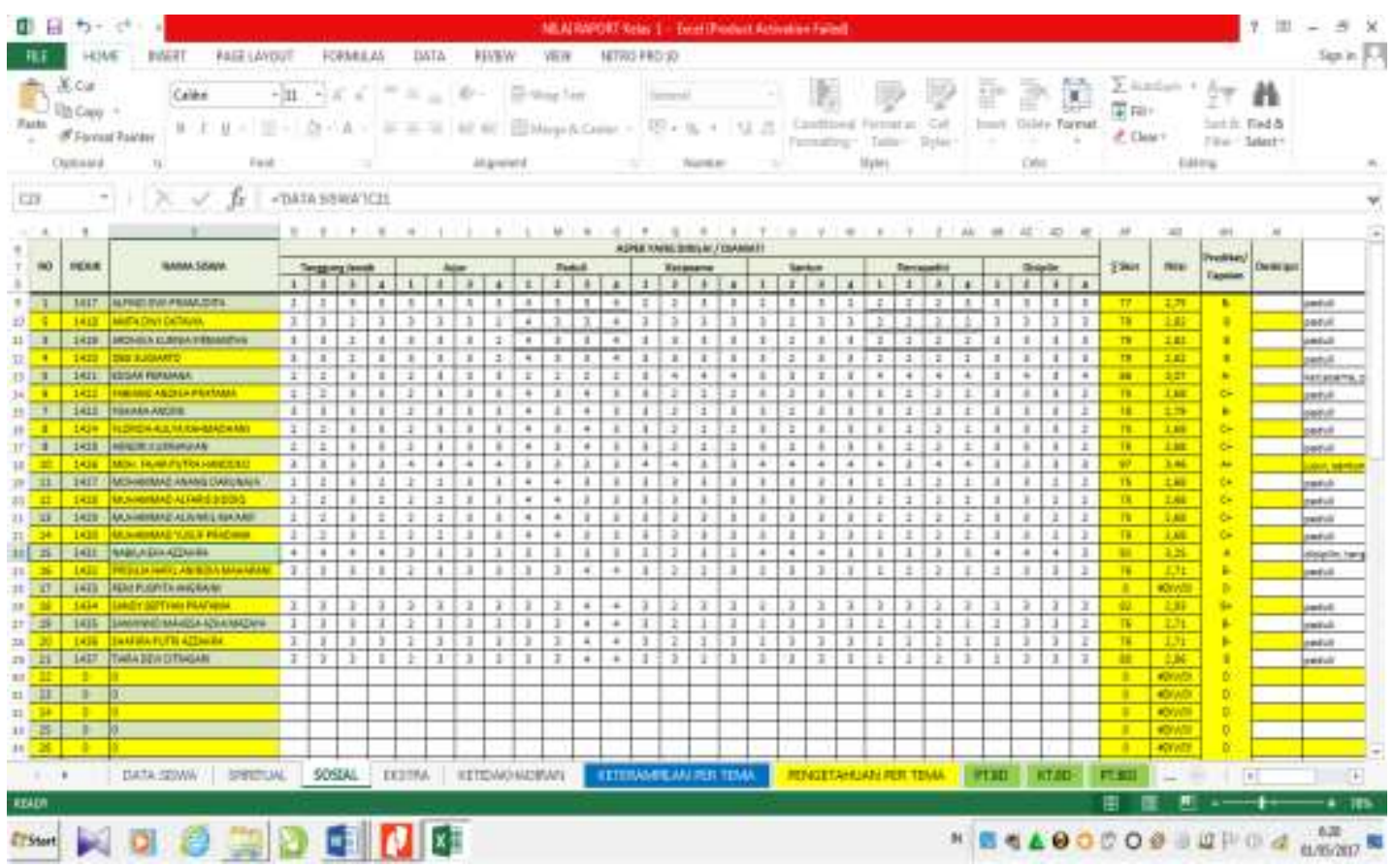

Gambar 4 Nilai sosial siswa

\section{Ektrakurikuler}


Penilaian ektrakurikuler adalah capaian siswa pada kegiatan ekstra yang diikutinya

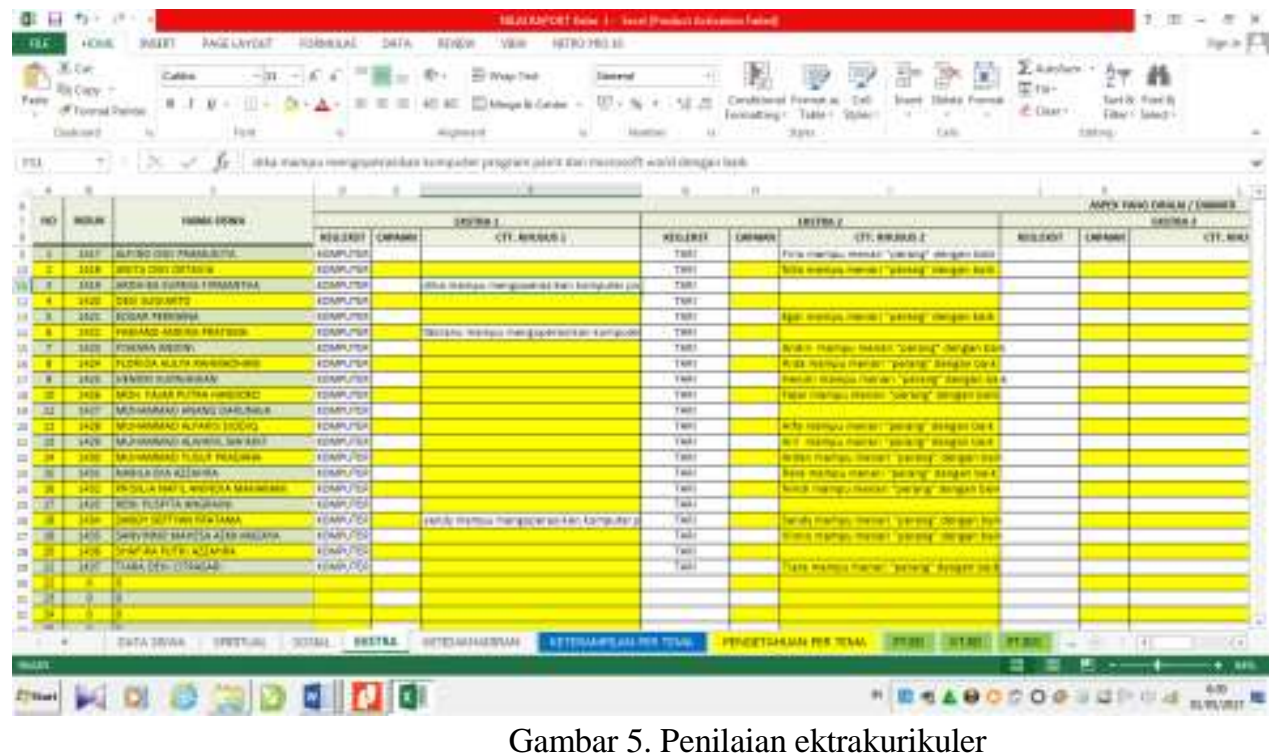

5. Ketidakhadiran

Ketidakhadiran merupakan hasil rekap kedisiplinan siswa dalam mengikuti pelajaran selama hari efektif dalam satu semester

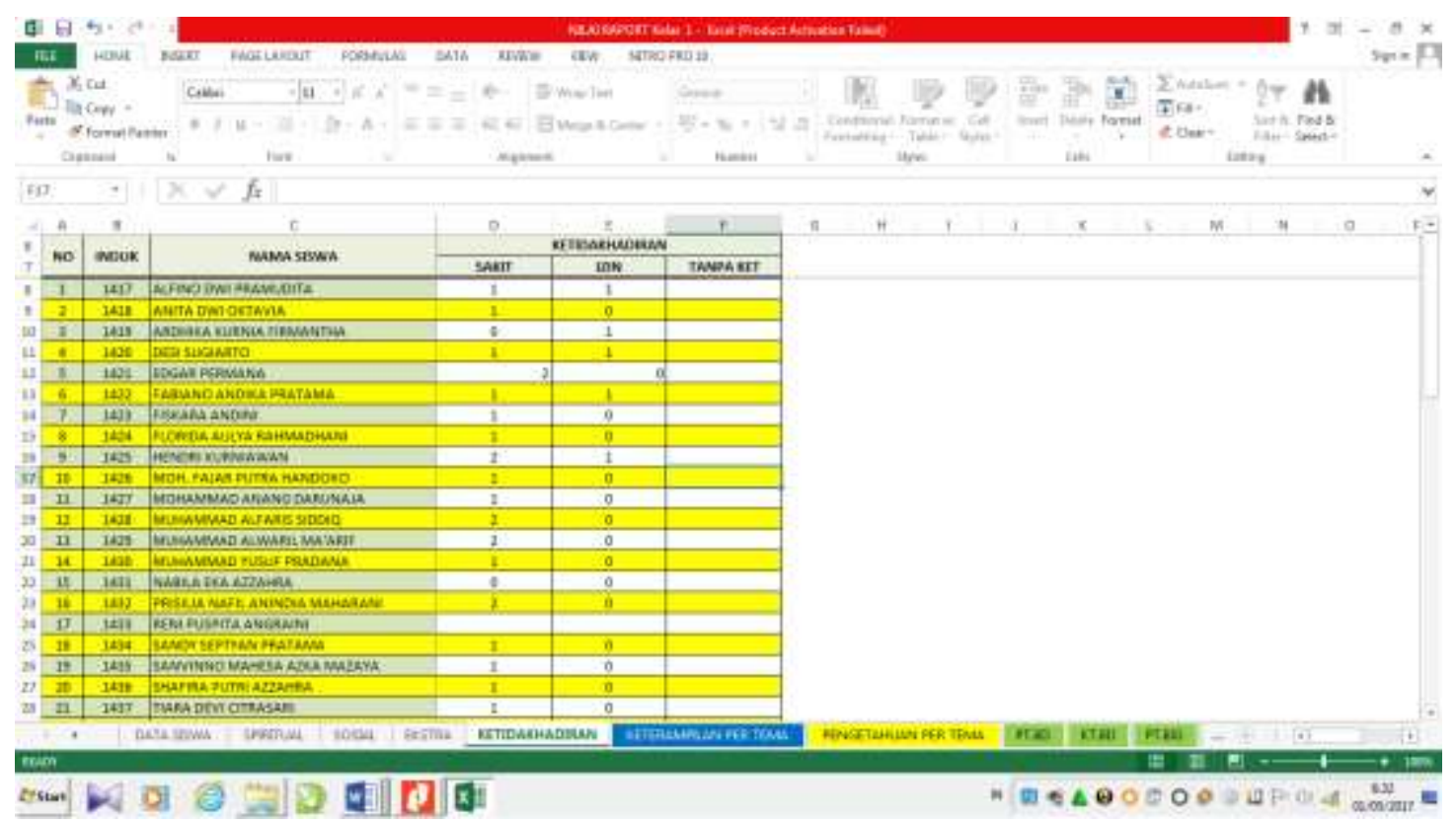

Gambar 6. Ketidakhadiran siswa

\section{Ketrampilan pertema}


Ketrampilan per tema merupakan nilai ketrampilan atau praktik siswa yang diperoleh dari beberapa mata pelajaran yang tergabung dalam satu tema

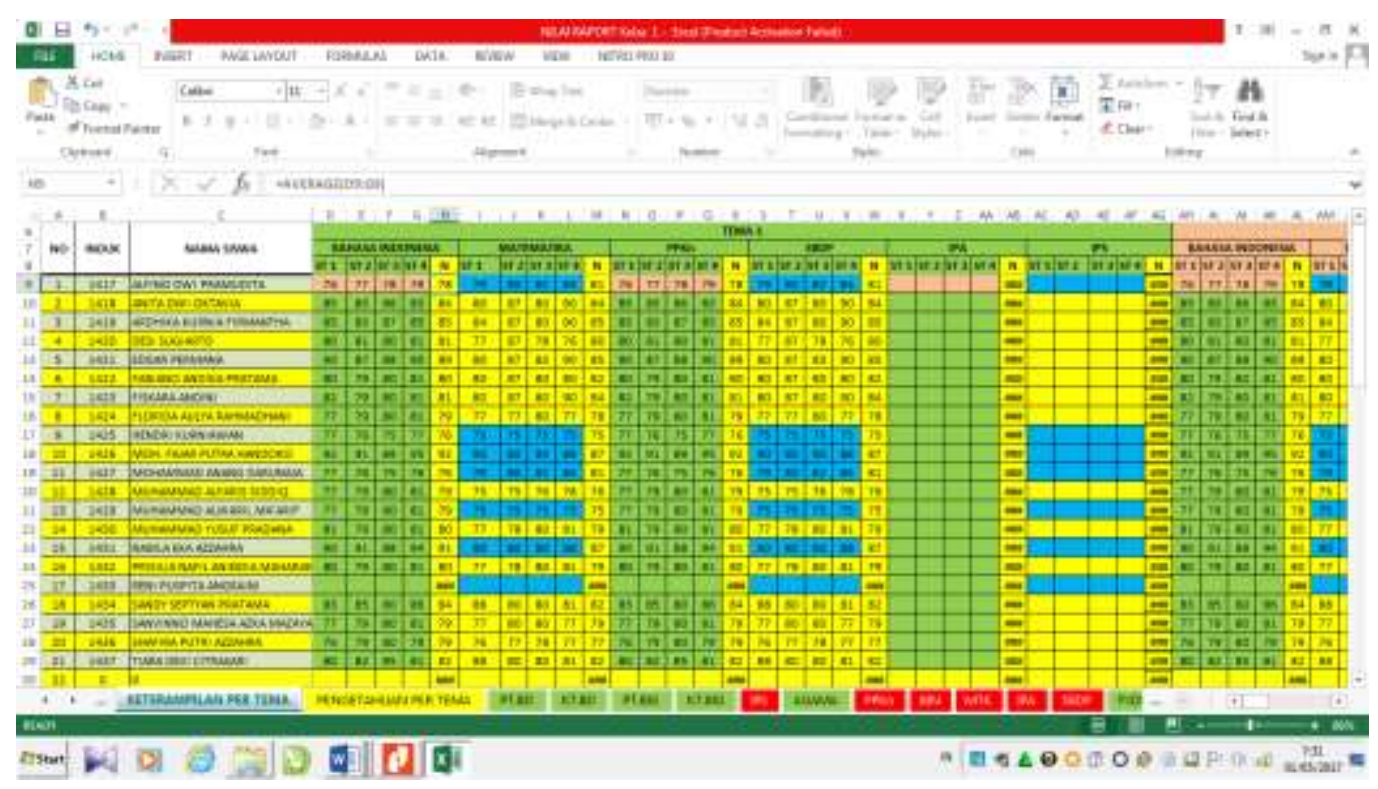

Gambar 7. Ketrampilan per Tema

7. Pengetahuan pertema

Pengetahuan per tema merupakan nilai pengetahuan atau kognitif siswa yang diperoleh dari beberapa mata pelajaran yang tergabung dalam satu tema 


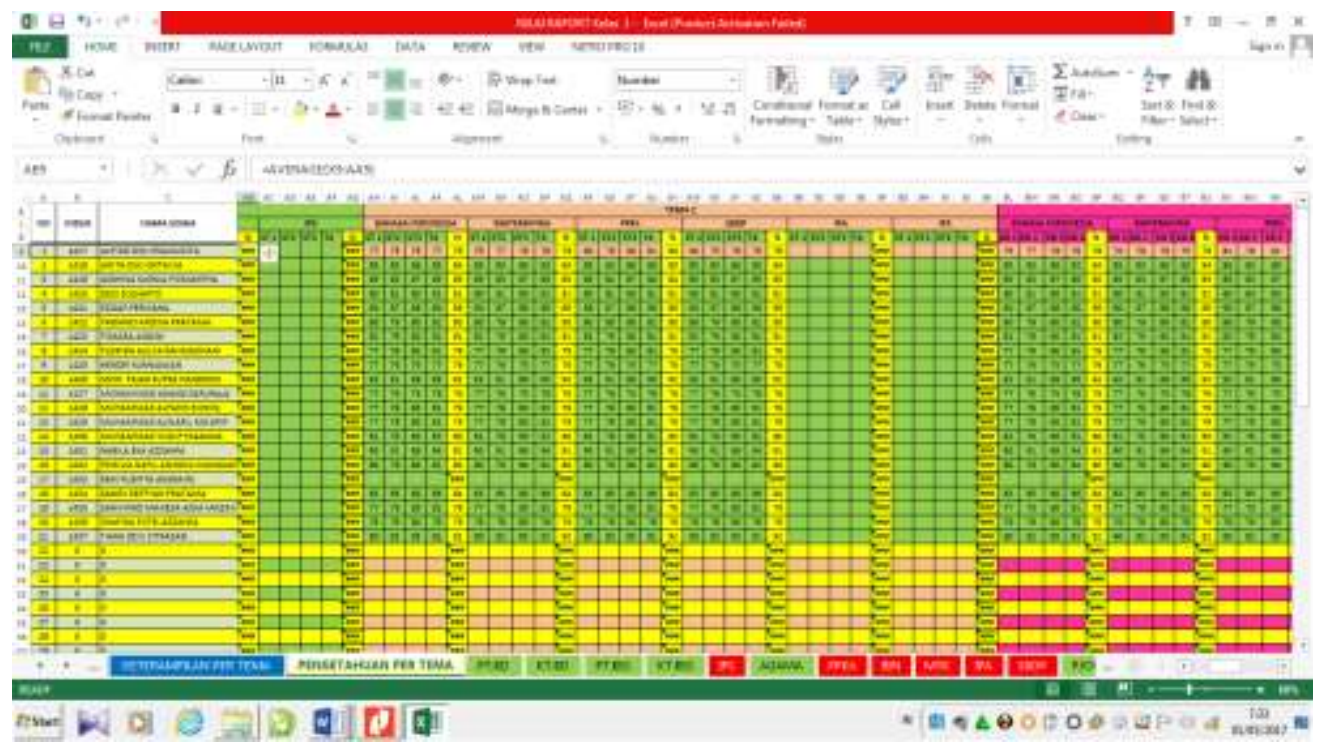

Gambar 8. Pengetahuan per Tema

8. Pengetahuan Bahasa Daerah dan Ketrampilan Bahasa Daerah

Pengetahuan Bahasa Daerah dan Ketrampilan Bahasa Daerah merupakan nilai praktik dan kognitif siswa. Bahasa daerah berdiri sendiri tidak tergabung dalam satu tema.
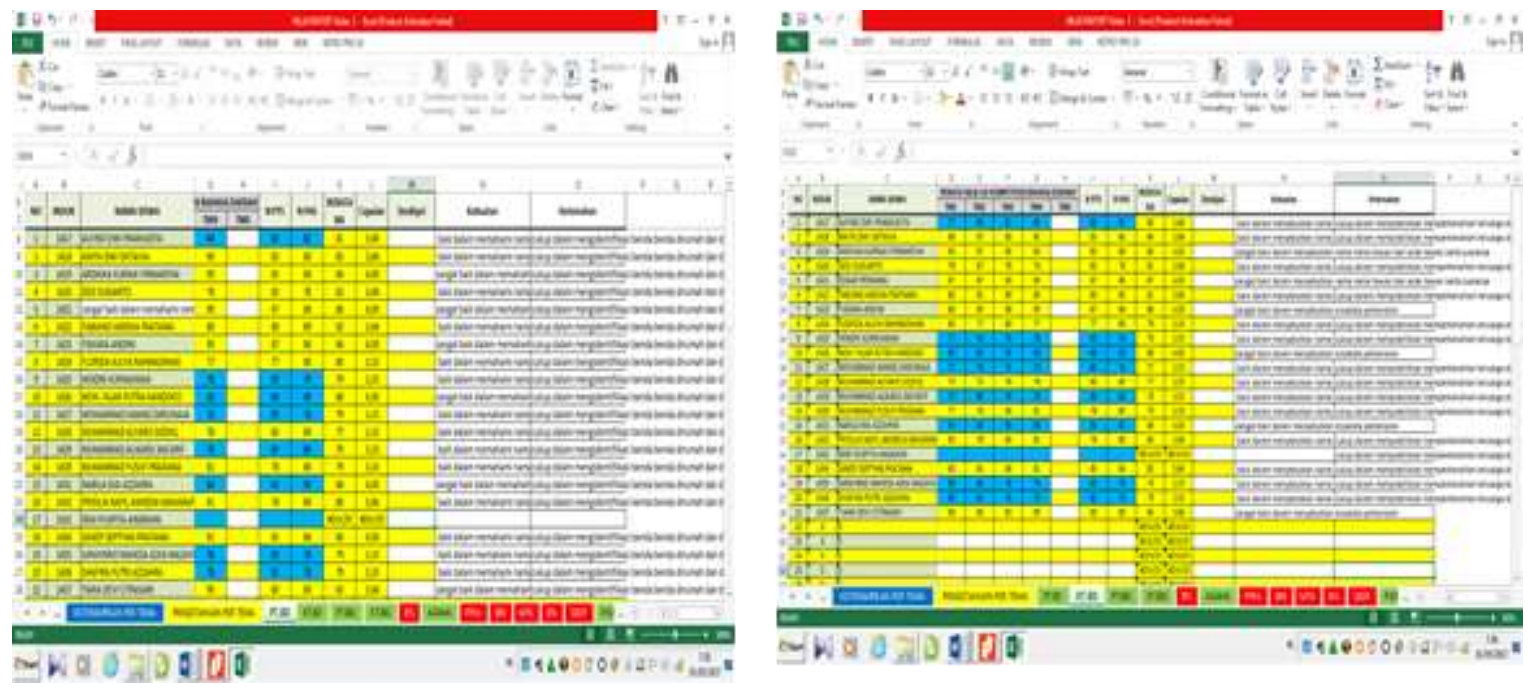

Gambar 9. Pengetahuan Bahasa Daerah dan Ketrampilan Bahasa Daerah

9. Agama, Pendidikan Kewarganegaraan, Bahasa Indonesia, Matematika, SBDP, dan PJOK 
Nilai rata rata pengetahuan dari masing masing tema secara langsung masuk pada kolom nilai mata pelajaran Agama, Pendidikan Kewarganegaraan, Bahasa Indonesia, Matematika, SBDP, dan PJOK. Pada format nilai mata pelajaran, guru memberikan catatan kekuatan dan kelemahan siswa dalam ketrampilan mata pelajaran yang dipelajari. Berikut gambar salah satu nilai mata pelajaran:

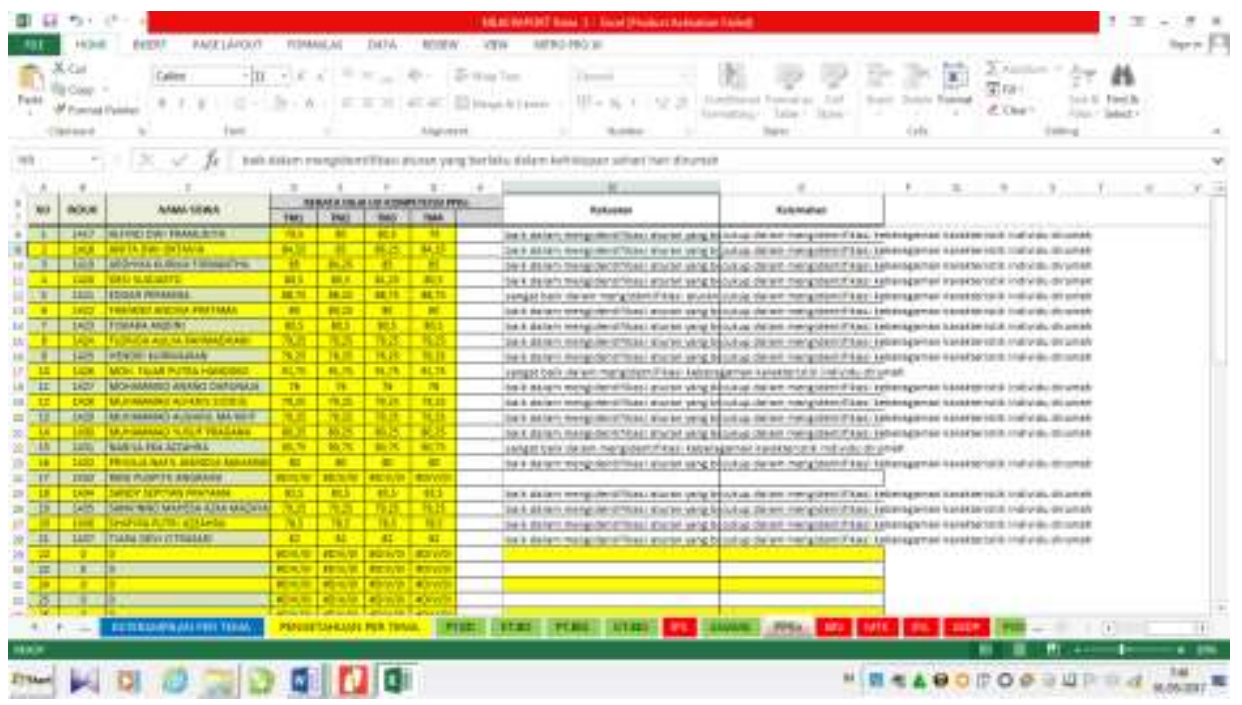

Gambar 10. Nilai mata pelajaran (pengetahuan)

10. PJOK (2), Agama (2), Matematika (2), SBDP (2)

Nilai rata rata ketrampilan dari masing masing tema secara langsung masuk pada kolom nilai mata pelajaran PJOK (2), Agama (2), Matematika (2), SBDP (2). Pada format nilai mata pelajaran, guru memberikan catatan kekuatan dan kelemahan siswa dalam ketrampilan mata pelajaran yang dipelajari. Berikut gambar salah satu nilai mata pelajaran: 


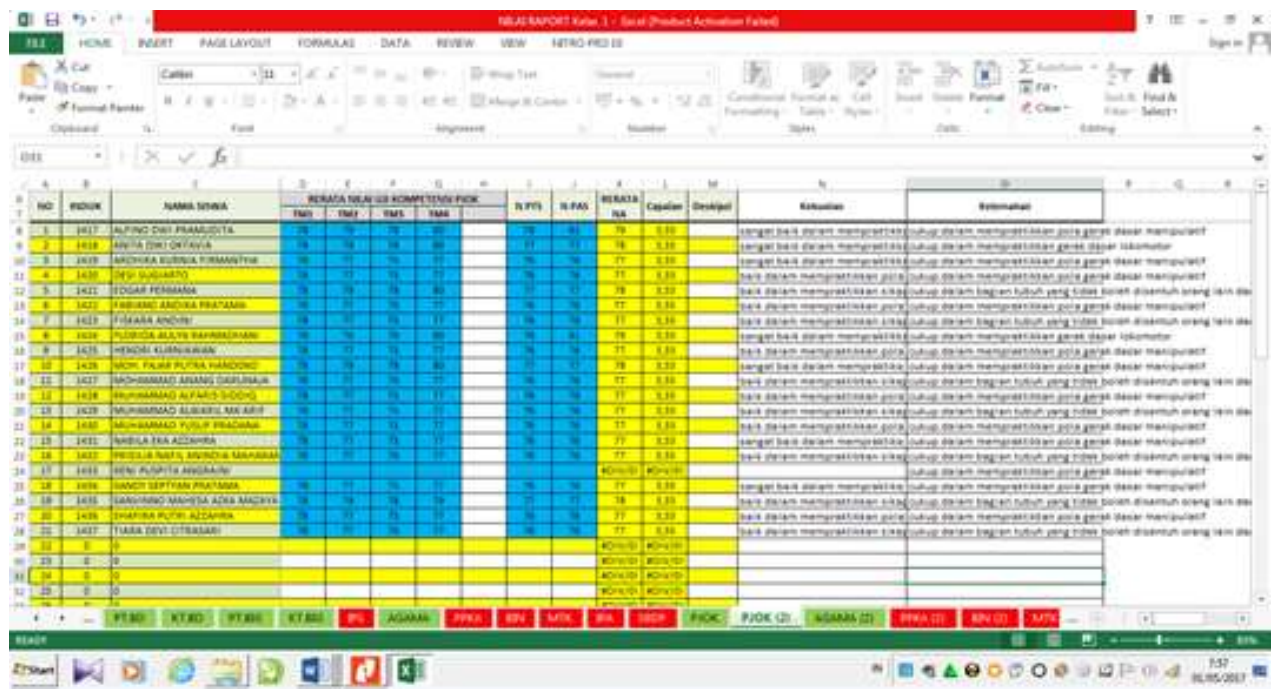

Gambar 11. Nilai Mata Pelajaran (Ketrampilan)

\section{Kondisi Fisik Siswa}

Keadaan atau kondisi fisik siswa meliputi keterangan masing masing siswa tentang tinggi badan, berat badan, aspek penglihatan, aspek pendengaran, dan aspek kesehatan gigi.

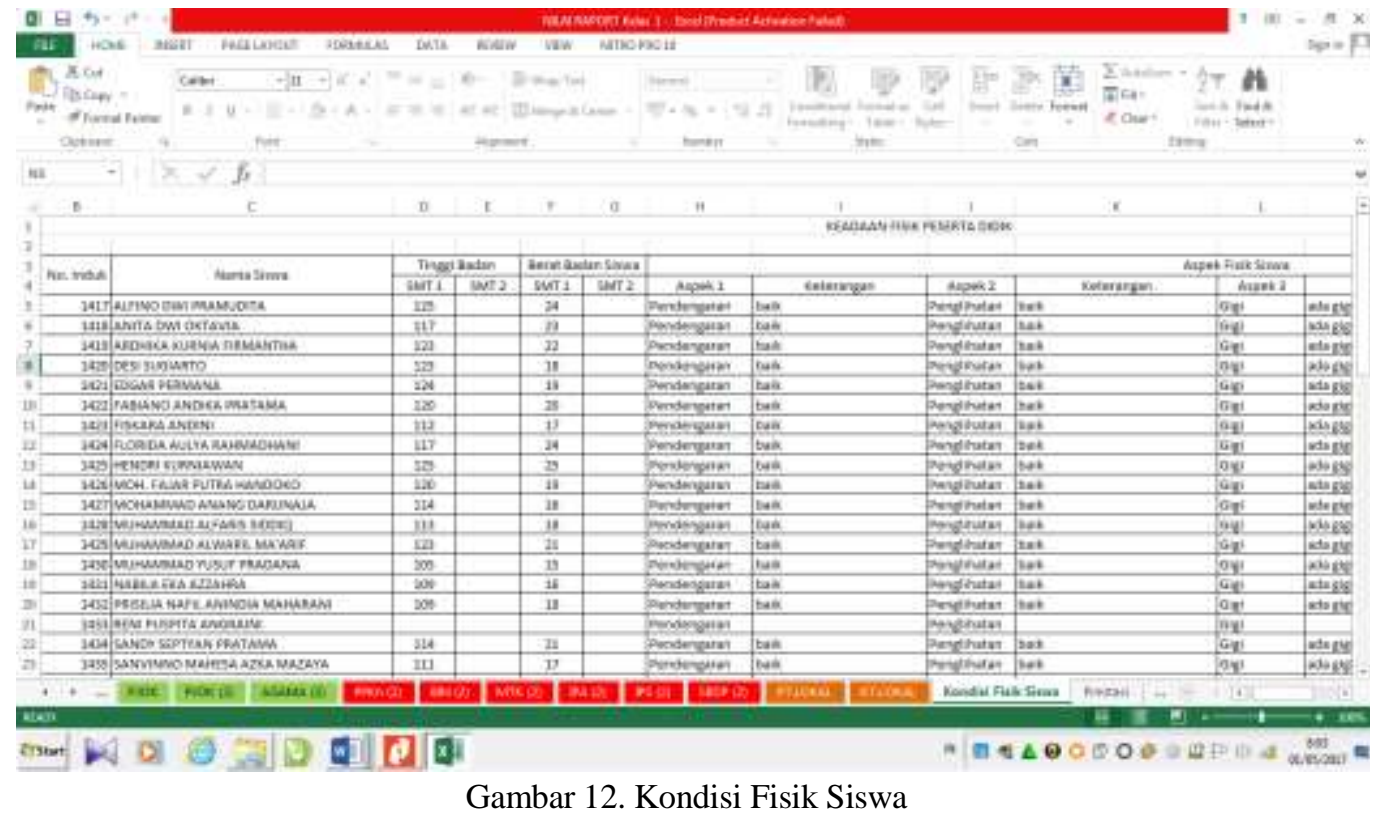

Antivirus: Jurnal Ilmiah dan Teknik Informatika, Mei 2017, Vol.11, No. 1 
12. Prestasi

Kolom prestasi memuat sederet prestasi yang diraih siswa mulai dari prestasi tingkat sekolah hingga tingkat nasional

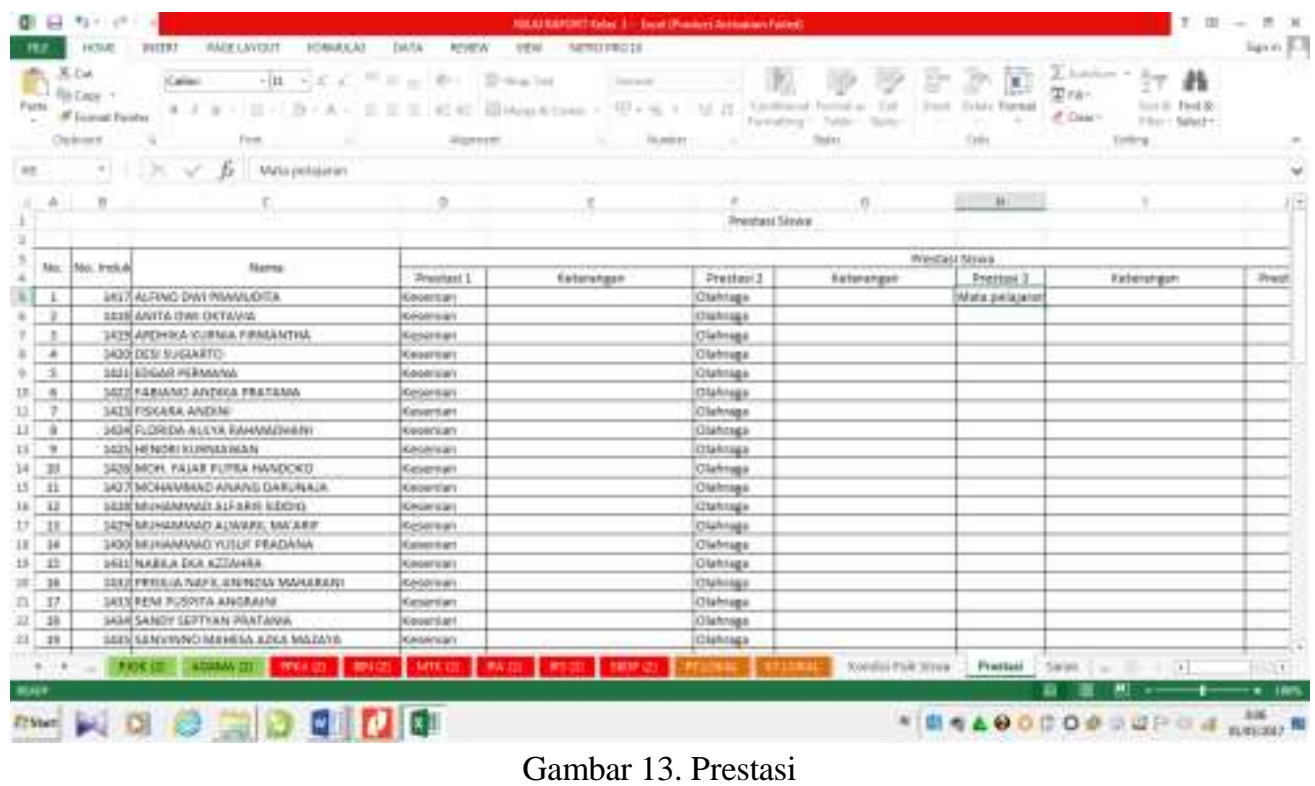

\section{Saran}

Saran berupa catatan guru untuk siswa yang bersifat mendorong dan perbaikan perbaikan yang harus dilakukan siswa untuk mendapatkan prestasi yang lebih baik. 


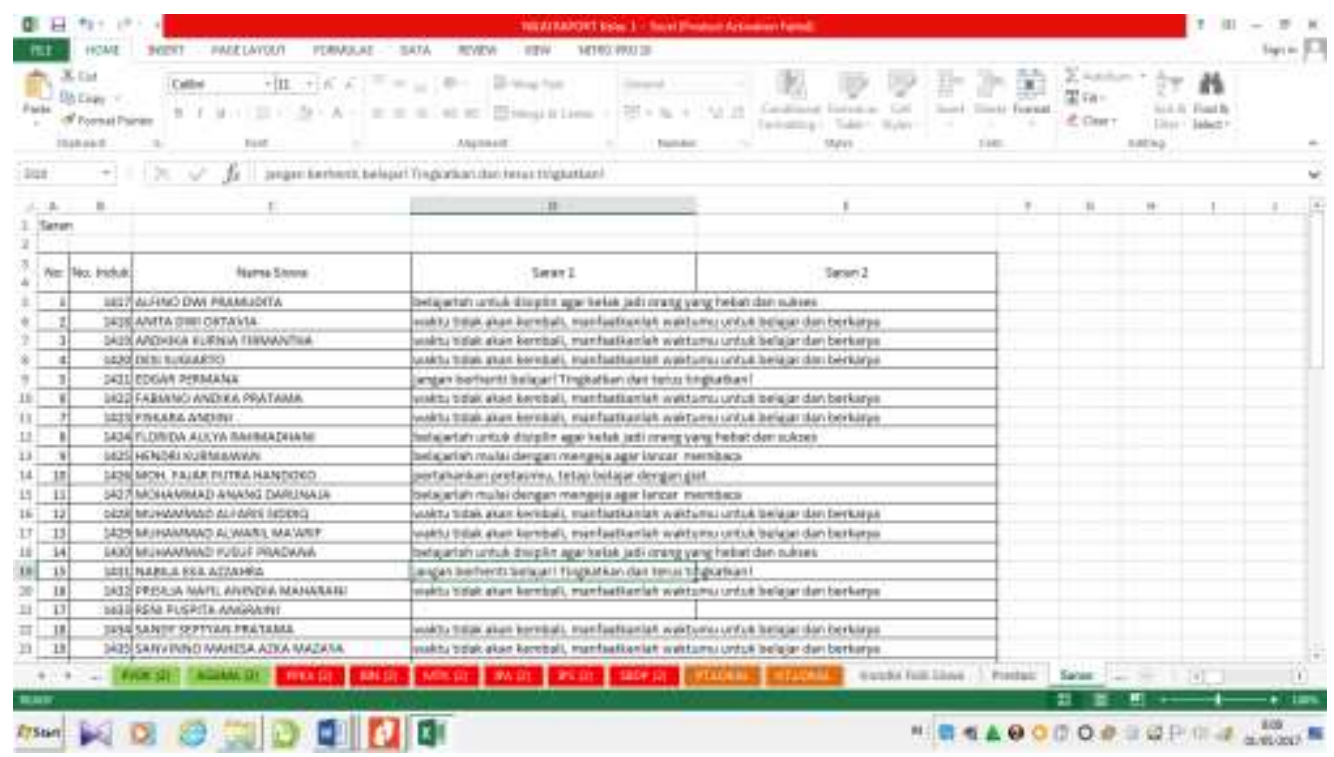

Gambar 14. Saran

14. Raport siswa

Setelah mengisikan nilai pada format nilai dimicrosoft excel, maka guru dapat membuka microsoft word yang sudah di link kan pada microsoft excel. Sehingga akan mendapat tampilan seperti berikut :

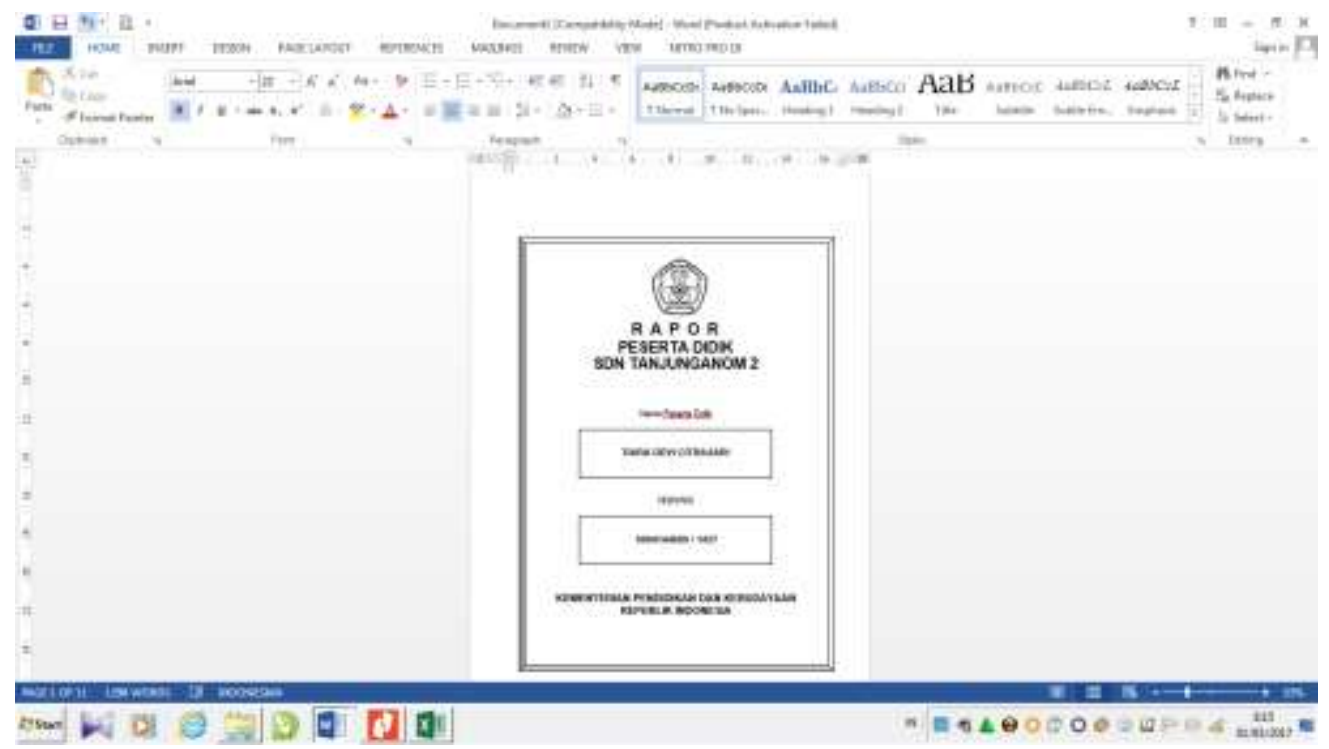

Gambar 15. tampilan depan raport siswa 
Ada 11 halaman untuk raport siswa yang menggunakan kurikulum 2013. Halaman penilaian seperti tampak pada gambar berikut :

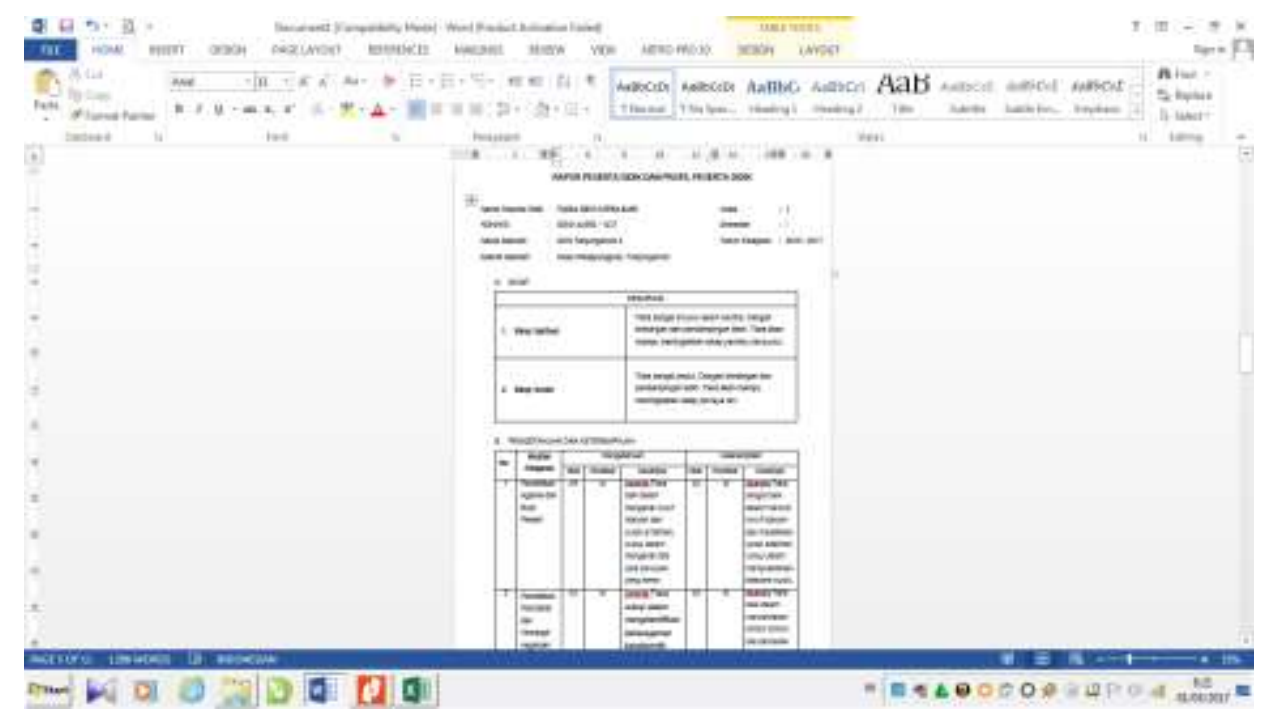

Gambar 16. tampilan halaman penilaian

\section{b. Kelebihan dan kekurangan}

Dalam aplikasi ini, terdapat kelebihan dan kekurangan. Hal ini disebabkan karena sistem belum berjalan dengan baik. Beberapa kekurangan dan kelebihan tersebut sebagai berikut :

1. Kelebihan

Program mempunyai fasilitas pendataan siswa guru, kelas, mata pelajaran, walikelas serta nilai dan raport siswa

2. Kekurangan

a. Belum menggunakan client server untuk menginput dan mengoutput data

b. Penulisan kelebihan dan kelemahan siswa belum otomatis dari nilai tertinggi dan terendah tetapi guru maupun oprator masih harus menulisnya secara manual

\section{a. Kesimpulan}

\section{SIMPULAN DAN SARAN}

Berdasarkan hasil penelitian maka dapat disimpulkan bahwa penggunaaan aplikasi microsoft excel sangat membantu dalam proses penilaian secara tepat. Aplikasi penilaian ini memiliki fasilitas pendataan siswa yang terdiri dari identitas siswa, keluarga siswa dan kelas siswa, guru yang terdiri dari guru 
pengampu mata pelajaran dan walikelas, kelas, ekstrakulikuler, mata pelajaran, serta penilaian yang terdiri dari penilaian spiritual, sosial, ketrampilan pertema, pengetahuan pertema, hingga saran untuk siswa. Jadi, aplikasi ini sangat disarankan untuk digunakan dalam pengolahan nilai siswa pada sekolah sekolah yang sudah menerapkan kurikulum 2013

b. Saran

Terbatasnya waktu dan kemampuan dari kegiatan penelitian yang dilakukan penulis, maka dikemukakan saran sebagai berikut:

1. Diharapkan program ini dapat dikembangkan menjadi program dengan menggunakan sistem client server sehingga aplikasi ini dapat digunakan secara lebih baik serta optimal.

2. Diharapkan pada bagian laporan penilaian dapat dibuat secara terperinci karena laporan nilai yang ditampilkan pada program ini hanya dalam bentuk raport.

\section{DAFTAR PUSTAKA}

Andri, Kristanto. 2003. Perancangan Sistem Informasi. Gava Media, Yogyakarta.

Hartanto, Yogiyanto. 2000. Pengenalan Komputer. Yogyakarta: Andi Yogyakarta

(online), http://domino2007.wordpress.com di akses tanggal 21 Maret 2017

Parwanti dkk, Sistem Komputerisasi Pengolahan Nilai Raport Secara Multiuser pada SMA Muhamadiyah Surakarta, Jurnal TiKomSin

Sutarman. 2012. Membangun Aplikasi Web dengan PHP dan MySQL. Yogyakarta: Graha Ilmu.

Tim Penyusun. 2015. Panduan Penilaian Untuk Sekolah Dasar. Kementrian Pendidikan dan Kebudayaan Direktorat Jenderal Pendidikan Dasar dan Menengah. Direktorat Pembinaan Sekolah Dasar.

Tim penyusun Kamus Pusat Pembinaan dan Pengembangan Bahasa. 1988, Kamus Bahasa Indonesia, Balai Pustaka, Jakarta. 